BESTARI

Vol. 17, No. 1, 2020

p-ISSN 1907-1337; e-ISSN 2807-6532

\title{
Pengaruh Penggunaan Aplikasi Quizizz terhadap Efektivitas Pembelajaran Pendidikan Agama Islam
}

\author{
Syifa Agestrisna Nur 'Amanah \\ Institut Agama Islam Darussalam (IAID), Ciamis-Jawa Barat \\ Email: syifa.agestrisnanuramanah @gmail.com \\ Cecep Darul Iwan \\ Institut Agama Islam Darussalam (IAID), Ciamis-Jawa Barat \\ Selamet \\ Institut Agama Islam Darussalam (IAID), Ciamis-Jawa Barat
}

\begin{abstract}
This study aims to: 1) determine how to use the Quizizz application at SDN 3 Cisaga, 2) find out how the effectiveness of Islamic Education learning at SDN 3 Cisaga, 3) determine whether there is an effect of using the Quizizz application on the effectiveness of Islamic Education learning at SDN 3 Cisaga. This research is a quantitative research with an experimental approach, the population in this study is the upper class (class 4, 5 and 6) at SDN 3 Cisaga, amounting to 56 people, while the sampling technique uses stratifield random sampling technique which is used as the entire population as a sample if the population less than 100. Which means, the sample was taken as a whole with a total of 56 people. Data collection was done by using a questionnaire technique. The data analysis technique used is inferential statistical analysis, independent analysis of the sample T test. The results of this study indicate that: 1) The use of the Quizizz application is in moderate qualification by reaching an average value of 80.17, this indicates that the use of the Quizizz application is in the range of 75.86 to 84.46. 2) The effectiveness of Islamic Education Learning is in moderate qualification as well as reaching an average value of 83.75 , this shows that the effectiveness of Islamic Education Learning is in the range of 81.08 to 86.40 .3 ) The use of the Quizizz application has an influence on the effectiveness of Islamic Education learning, this is indicated by the calculations that have been carried out by researchers, from the calculation results obtained through the significant test of the correlation coefficient at the 5\% significance level obtained tcount $>$ ttable $(8.132>2.004)$ and the sig or probability $<0.05$ (0.000 <0.05), indicating that statistically the use of the Quizizz application has a significant effect between learning using the Quizizz application on the effectiveness of PAI learning so that Ho is rejected and Ha is accepted.
\end{abstract}

Keywords: Quizizz application, PAI learning 


\section{PENDAHULUAN}

Pendidikan merupakan kebutuhan pokok yang wajib didapatkan oleh setiap manusia baik anak-anak ataupun orang dewasa. Pendidikan menjadi salah satu modal bagi seseorang untuk menuju keberhasilan dan kesuksesan dalam hidupnya. Untuk itu, pemerintah terus berusaha dalam memperbaiki sistem pendidikan dengan memperbaiki kurikulum yang ada, kurikulum yang menjadi acuan dalam proses pembelajaran terus berkembang dan akan selalu mengalami perbaikan.

Pendidik berperan penting dalam upaya meningkatkan mutu pendidikan. Dalam hal ini, pendidik harus mengajar dengan profesional, yang mampu menyuguhkan suatu pengajaran yang menarik. Artinya, pendidik harus mampu memilih metode pengajaran dan menentukan media dan sumber belajarnya. Dengan kemajuan teknologi, pendidik dituntut untuk lebih kreatif dalam menyampaikan materi pembelajarannya, untuk itulah dibutuhkan teknologi pendidikan. Dan pendidikan tidak hanya disampaikan melalui pola tradisional, tetapi perlu pemanfaatan teknologi terhadap pendidikan.

Teknologi pendidikan adalah suatu penerapan teknologi yang mendukung kegiatan pendidikan atau pengajaran sebagai alat bantu untuk memperbaiki dan meningkatkan proses belajar manusia. Aplikasi teknologi pendidikan sangat relevan bagi pengelolaan pendidikan pada umumnya dan kegiatan belajar mengajar pada khususnya. Aplikasinya adalah teknologi pendidikan memungkinkan adanya perubahan kurikulum, baik strategi, pengembangan maupun aplikasinya, teknologi pendidikan menghilangkan walaupun tidak keseluruhan pola pengajaran tradisional (Switri, 2019: 1).

Mobile learning adalah pembelajaran yang memanfaatkan teknologi dan perangkat mobile. Dalam hal ini perangkat tersebut dapat berupa PDA, telepon seluler, laptop, tablet PC, dan sebagainya. Dengan mobile learning, pengguna dapat mengakses konten pembelajaran dimana saja dan kapan saja tanpa harus mengunjungi suatu tempat tertentu pada waktu tertentu (Herlina dan Habibi, Prosiding SENTIA, 8, 2016: A254). Jadi, pengguna dapat mengakses konten pendidikan tanpa terikat ruang dan waktu. Haryono dan Alatas dalam buku (Jalinus \& Ambiyar: 2016: 219) menyiratkan bahwa e-learning merupakan konsep belajar jarak jauh dengan menggunakan tekonologi telekomunikasi dan informasi. Berdasarkan definisi tersebut, bahwa mobile learning merupakan model pembelajaran yang memanfaatkan teknologi informasi dan komunikasi. Pada konsep tersebut, membawa manfaat ketersediaan materi ajar yang dapat diakses setiap saat dan visualisasi materi yang menarik.

Pendidikan Agama Islam (PAI) di Sekolah Dasar, dalam pelaksanaannya masih menunjukkan berbagai permasahalan yang kurang menyenangkan. Seperti halnya proses pembelajaran Pendidikan Agama Islam (PAI) di sekolah saat ini masih sebatas sebagai proses penyampaian "pengetahuan tentang Agama Islam." Hanya sedikit yang arahnya pada 


\section{BESTARI}

Vol. 17, No. 1, 2020

p-ISSN 1907-1337; e-ISSN 2807-6532

proses internalisasi nilai-nilai Islam pada diri peserta didik. Hal ini dapat dilihat dari proses pembelajaran yang dilakukan pendidik masih dominan ceramah.

Berkembangnya teknologi mempermudah dalam melakukan segala hal. Demikian pula halnya dalam bidang pendidikan, teknologi akan mempermudah pendidik dalam melaksanakan tugas-tugasnya dalam kelas. Salah satu penggunaan teknologi dalam pembelajaran misalnya menggunakan kuis interaktif di kelas menggunakan sebuah aplikasi interaktif yaitu Quizizz.

Quizizz merupakan sebuah web tool untuk membuat permainan kuis interaktif untuk digunakan dalam pembelajaran di kelas, misalnya saja untuk penilaian formatif. Penggunaannya sangat mudah, kuis interaktif yang dibuat memiliki hingga 4 pilihan jawaban termasuk jawaban yang benar. Bisa ditambahkan dengan gambar ke latar belakang pertanyaan dan menyesuaikan pengaturan pertanyaan sesuai keinginan.

Pemilihan dengan aplikasi Quizizz ini bertujuan untuk mencapai suatu pembelajaran yang efektif dengan menggunakan teknologi dan membuat peserta didik untuk lebih bisa berpikir kritis. Dan bertujuan untuk mencapai dan melihat pengaruhnya efektivitas pembelajaraan menggunakan teknologi. Dan diharapkan materi pembelajaran PAI dapat mudah dipahami dan dapat meningkatkan efektivitas belajar peserta didik. Dalam pelaksanaan pembelajaran, peserta didik dapat mempelajari ilmu pengetahuan secara kognitif, belajar melakukan berdasarkan pengalaman, dan belajar hidup dalam kebersamaan.

Uraian diatas dapat disimpulkan bahwa pendidik sebagai pengajar sekaligus pendidik di Sekolah Dasar memiliki ide mengajar dengan aplikasi dan dalam pembelajaran tersebut melibatkan interaksi dan komunikasi antara pendidik dan peserta didik dengan jarak jauh.

\section{KAJIAN TEORI}

Pengertian E-learning

E-learning merupakan salah satu strategi atau metode pembelajaran paling efektif yang mampu menjangkau tempat yang sangat luas, dengan biaya yang relatif murah. Untuk mengakses materi pembelajaran pada e-learning diperlukan komputer dengan jaringan internet intranet. Materi pembelajaran selalu ada kapanpun dan di mana pun dibutuhkan. Sehingga dapat mengatasi kendala jarak, ruang dan waktu. Dengan demikian, pembelajaran melalui e-learning bisa berlangsung kapan saja, di mana saja, melalui jalur mana saja dengan kecepatan apapun. Dalam pembelajaran itu pengajar dan pembelajar tidak perlu berada pada tempat dan waktu yang sama untuk melangsungkan proses pembelajaran, namun cukup dengan menggunakan internet sebagai medianya. Aplikasi Quizizz 
Quizizz adalah aplikasi pendidikan yang berbasis game, yang membawa aktivitas multi pemain ke ruang kelas dan membuatnya di kelas latihan interaktif dan menyenangkan. Dengan menggunakan Quizizz, peserta didik dapat melakukan latihan di dalam kelas pada perangkat elektronik mereka. Quizizz juga dapat membuat peserta didik untuk saling bersaing dan memotivasi mereka belajar. Peserta didik mengambil kuis pada saat yang sama di kelas dan dapat melihat peringkat langsung mereka di papan peringkat. Aplikasi ini dapat membantu merangsang minat dan meningkatkan konsentrasi peserta didik (Purba, JDP, 12, 2019, 33).

Quizizz dapat digunakan sebagai strategi pembelajaran yang baik dan menyenangkan tanpa kehilangan esensi belajar yang sedang berlangsung. Bahkan strategi ini dapat melibatkan partisipasi peserta didik secara aktif sejak awal. Selain itu tuntutan dari era revolusi industi 4.o membuat berbagai sektor kehidupan termasuk bidang pendidikan perlu melakukan reorientasi dalam menentukan arah kebijakan pendidikan untuk menjawab tantangan revolusi industri 4.0 yang menuntut peningkatan kapasitas individu secara signifikan dan menyeluruh melalui berbagai efisiensi dalam dunia pendidikan, seperti sistem pendidkan yang melibatkan teknologi dalam proses pembelajaran (Noor, Jurnal Pendidikan Hayat, 1, 2020, 2).

1) Langkah-langkah Penggunaan Aplikasi Quizizz

Langkah-langkah penggunaan aplikasi ada beberapa bagian, yaitu langkah-langkah mendaftar akun dan langkah-langkah membuat kuis.

a) Langkah-langkah mendaftar akun

(1) Masuk ke situs https://quizizz.com/

(2) Klik sign up (dapat melalui akun google sendiri)

(3) Setelah berhasil sign up, silahkan klik a teacher

(4) Pilih negara

(5) Masukkan kode pos

(6) Masukkan nama sekolah secara manual dengan cara klik can't find your organization

(7) Klik add organization

(8) Klik continue

Sampai disini, telah sukses membuat akun di Quizizz.com.

b) Langkah-langkah membuat kuis

(1) Klik open quiz creator

(2) Masukkan nama kuis yang akan dibuat

(3) Pilih bahasa yang digunakan dalam kuis

(4) Masukkan gambar jika diperlukan

(5) Selesai, klik save

(6) Klik create new question untuk mulai membuat soal

(7) Dan jawaban bisa berupa multiple choice atau uraian

(8) Klik live game 


\section{BESTARI}

Vol. 17, No. 1, 2020

p-ISSN 1907-1337; e-ISSN 2807-6532

(9) Melakukan pengaturan dengan misalnya pertanyaan akan diacak, jawaban akan diacak, dan setelah peserta didik selesai menjawab akan diperlihatkan jawaban yang benar.

(10) Jika sudah selesai, tekan proceed. Maka kuis siap dibagikan kepada peserta didik dengan mengetik join.quizizz.com di browser hp androidnya (Ariyanti, 2019: 67-72).

2) Kelebihan dan Kelemahan Aplikasi Quizizz

a) Kelebihan Aplikasi Quizizz

(1) Setiap peserta didik menjawab pertanyaan dengan benar maka akan muncul beberapa poin yang didapatkan dalam satu soal dan juga mendapat ranking berapa dalam menjawab soal tersebut

(2) Jika peserta didik menjawab salah pertanyaan tersebut, maka akan muncul jawaban yang benar

(3) Jika selesai mengerjakan kuis, pada akhir kuis akan ada tampilan Review Question untuk melihat kembali jawaban yang dipilih

(4) Dalam pengerjaan kuis, setiap peserta didik mendapat daftar pertanyaan yang berbeda dengan peserta didik yang lainnya karena kuis tersebut dibuat dalam bentuk Homework/PR sehingga daftar soalnya diacak setiap peserta didik dan soal yang muncul akan berbeda-beda

b) Kelemahan Aplikasi Quizizz

(1) Peserta didik dapat membuka tab baru

(2) Susah dalam mengontrol peserta didik ketika membuka tab baru (Nugroho, 2019: 6-7).

3) Manfaat Quizizz dalam Pendidikan

a) Penggunaan aplikasi yang mengenalkan metode baru untuk dalam pembelajaran. Dan peserta didik pun dapat lebih bisa berpikir kritis.

b) Lebih mudah dalam melaksanakan tugas pembelajaran dengan waktu yang ditentukan.

c) Suasana pembelajaran yang lebih seru, lebih menyenangkan, lebih menantang dan tidak membuat jenuh bagi peserta didik

Efektivitas Pembelajaran PAI

Pendidikan agama Islam merupakan usaha sadar yang dilakukan pendidik dalam rangka mempersiapkan peserta didik untuk meyakini, memahami dan mengamalkan ajaran Islam melalui kegiatan bimbingan, pengajaran atau pelatihan yang telah ditentukan untuk mencapai tujuan yang telah ditetapkan. Zakiyah Darajat berpendapat bahwa pendidikan agama islam adalah suatu usaha untuk membina dan mengasuh peserta didik agar senantiasa dapat memahami ajaran Islam secara menyeluruh. Lalu menghayati tujuan yang pada akhirnya dapat mengamalkan serta menjadikan Islam sebagai pandangan hidup (Darajat, 2008: 87).

Sedangkan pembelajaran pendidikan agama Islam adalah suatu upaya membuat peserta didik dapat belajar, butuh belajar, terdorong belajar, mau belajar, dan tertarik untuk terus menerus mempelajari 
agama Islam, baik untuk kepentingan mengetahui bagaimana cara beragama yang benar maupun mempelajari Islam sebagai pengetahuan yang mengakibatkan beberapa perubahan yang relatif tetap dalam tingkah laku seseorang yang baik dalam kognitif, afektif, dan psikomotorik (Majid, dkk, 2016: 132).

Adapun dari pengertian efektivitas, yaitu tentang arti tercapainya sasaran atau tujuan yang telah ditetapkan adalah proses pembelajaran mempunyai tolak ukur bagi peserta didik di dalam pembelajaran itu sendiri. Katapembelajaran berasal dari kata "belajar" yang mendapat awalan "pe" danakhiran "an". Keduanya (pe-an) termasuk konfiks nominal yang bertalian dengan perfiks verbal "me" yang mempunyai arti proses, cara, perbuatan yang menjadikan orang/makhluk hidup belajar (Pusat Bahasa Departemen Pendidikan Nasional, 2005: 17).

\section{METODE}

Penelitian kuantitatif adalah penelitian yang menguji sebuah teori dengan analisis data menggunakan numerik atau angka untuk membuktikan sebuah data yang benar (Sarmanu, 2017: 2).

Metode penelitian kuantitatif ialah metode penelitian yang pendekatan pada eksperimental, digunakan untuk menggambarkan fenomena-fenomena yang ada, yang berlangsung pada saat ini atau masa yang lampau. Menggunakan hipotesis yang digunakan sejak awal penelitian, reduksi data-data menjadi angka, penilaian validitas menggunakan berbagai prosedur dengan mengandalkan hitungan statistik (Hamdi \& Bahruddin, 2014: 4-6).

Tujuan penelitian ini untuk mengetahui berpengaruh tidaknya penggunaan aplikasi Quizizz terhadap efektivitas pembelajaran PAI.

Dalam pengumpulan informasi dan data yang diperlukan, peneliti menggunakan satu teknik yaitu:

Teknik Kuesioner (Angket) adalah teknik ini digunakan untuk mengumpulkan data dengan cara memberikan seperangkat pertanyaan atau pernyataan kepada responden untuk djawab. Kuesioner ini guna unuk mendapatkan informasi pribadi atau beberapa hal yang diketahui oleh responden. Kuesioner ini berisi pertanyaan-pertanyaan yang akan diajukan kepada peserta didik kelas atas di SDN 3 Cisaga untuk memperoleh data mengenai pengaruh penggunaan aplikasi Quizizz terhadap efektivitas pembelajaran PAI. Penyebaran kuesioner ini diberikan kepada sampel yang telah ditentukan yaitu seluruh peserta didik kelas atas di SDN 3 Cisaga.

Kuesioner yang digunakan dalam penelitian dapat dibuat dalam bentuk konvensional (cetak) atau dalam bentuk online (misalnya google form) (Riyanto dan Hatmawan, 2020: 29).

Analisis data penelitian merupakan langkah yang sangat penting dalam suatu penelitian. Analisis data yang diperolah dan diolah dengan benar dan tepat akan menghasilkan sebuah kesimpulan yang benar juga. 


\section{BESTARI}

Vol. 17, No. 1, 2020

p-ISSN 1907-1337; e-ISSN 2807-6532

Analisis yang dilakukan adalah uji normalitas, uji homogenitas dan uji hipotesis.

Uji distribusi normal merupakan uji untuk mengetahui dan mengukur apakah data yang didapatlan memiliki distribusi normal atau tidak dan apakah data yang diperoleh berasal dari populasi yang berdistribusi normal sehingga dapat dipakai dalam statistik parametrik (statistik inferensial). Tes-tes parametrik untuk uji normalitas dibangun dari distribusi normal (Gunawan, 2020: 52).

Uji normalitas penting dilakukan pada penelitian statistik parametrik, misalnya uji regresi linear, uji Anova, uji Ancova, uji Manova, uji Independen T Test, uji Paired T Test. Sedangkan jika data tesebut tidak berdistribusi normal akan lebih menggunakan metode penelitian dengan statistik non parametrik. Uji normalitas umumnya dilakukan menggunakan uji Kolmogorov-Smirnov dan uji Saphiro-Wilk (Herlina, 2019: 77-78).

Uji homogenitas digunakan untuk mengetahui apakah varian populasi adalah sama atau tidak. Uji ini dilakukan sebagai prasyarat dalam analisis independen sample $\mathrm{T}$ Test dan Anova. Asumsi yang mendasari dalam analisis varian (Anova) adalah bahwa varian dari populasi adalah sama. Sebagai kriteria pengujian, jika nilai signifikansi lebih dari 0,05 maka dapat dikatakan bahwa varian dari dua atau lebih kelompok data adalah sama. Sebagai kriteria pengujian, jika nilai signifikansi lebih dari 0,05 maka dapat dikatakan bahwa varian dari dua atau lebih kelompok data adalah sama (Gunawan, 2020: 68).

Uji hipotesis adalah suatu prosedur yang dilakukan dengan tujuan memutuskan apakah menerima atau menolak hipotesis ini. Dalam uji hipotesis, keputusan yang di buat mengandung ketidakpastian, artinya keputusan bisa benar atau salah, sehingga menimbulkan risiko. Besar kecilnya risiko dinyatakan dalam bentuk probabilitas (Payadnya dan Jayantika, 2018: 75).

Dalam melakukan pengujian hipotesis, peneliti melakukannya dengan: Uji T adalah uji yang menggunakan dua variabel dan mengetahui berpengaruh dan tidaknya variabel. Tujuan peneliti melakukan uji ini disampaikan Wicaksono (2005: 10) Uji T: paired two sample for means digunakan apabila dua variabel diperoleh dari sampel yang sama, atau dengan kata lain, data yang diperoleh dari kedua variabel yang diperbandingkan diperoleh dari subjek (sampel yang sama). 


\section{HASIL PENELITIAN DAN PEMBAHASAN}

1. Penggunaan Aplikasi Quizizz

Hasil pengolahan data secara deksriptif diperoleh angka-angka sebagai berikut.

Tabel 1. Deskrisi Statistik Penggunaan Aplikasi Quizizz

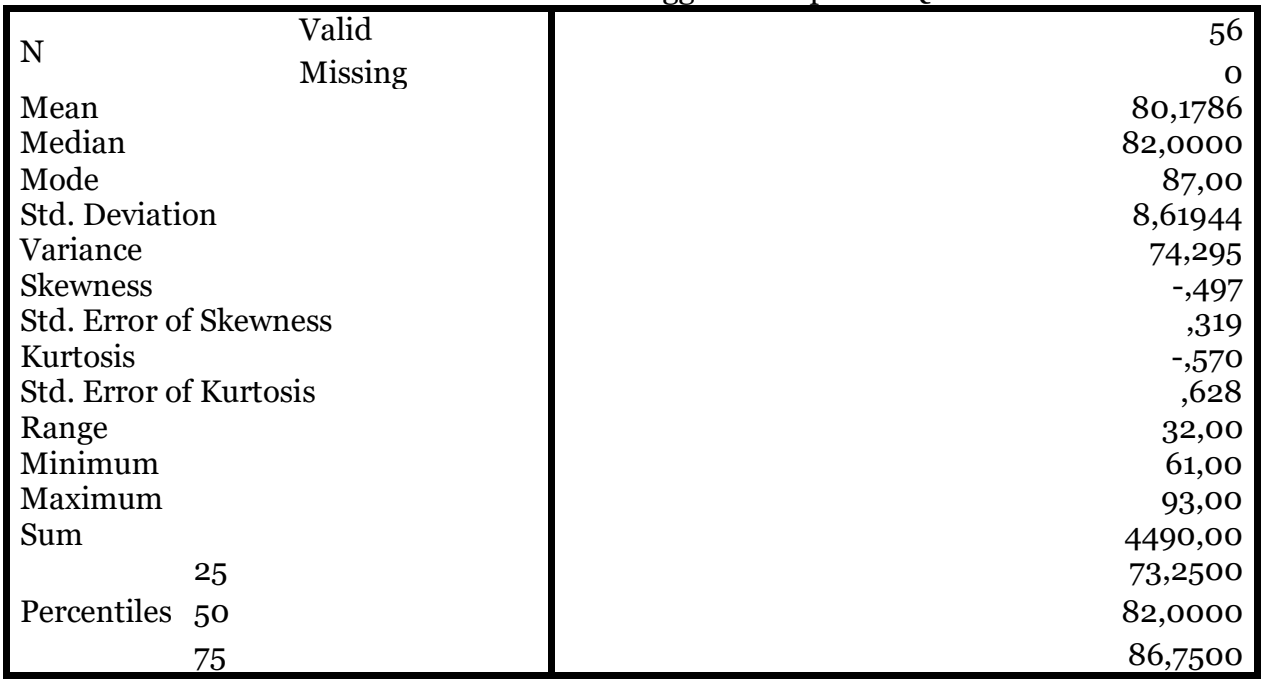

Berdasarkan hasil perhitungan di atas dapat diketahui bahwa:

a. Tendensi Sentral, sebagai berikut:

1) Mean sebesar 80,17. Harga mean tersebut peneliti konversikan dengan menggunakan pedoman konversi berikut:

Tabel 2. Konversi Harga Mean

\begin{tabular}{|c|c|}
\hline Skor & Kualifikasi \\
\hline$\geq 93,09$ & Sangat Tinggi \\
\hline $84,47-93,09$ & Tinggi \\
\hline $75,86-84,46$ & Sedang \\
\hline $67,24-75,85$ & Rendah \\
\hline$\leq 67,23$ & Sangat Rendah \\
\hline
\end{tabular}

Sumber: Sudijono (2015: 175)

Dengan demikian angka mean sebesar 80,17 tergolong sedang, sebab berada pada kisaran 75,86 sampai dengan 84,46.

2) Mediannya 82,00

3) Modusnya 87

b. Variabilitas, yaitu sebagai berikut:

1) Rangenya adalah 32,00

2) Standar deviasinya adalah 8,619

3) Variannya adalah 74,295

4) Quartil (Q)-nya adalah sebagai berikut: $\mathrm{Q}_{1}=73,25 ; \mathrm{Q}_{2}=82, \mathrm{oo}$; $\operatorname{dan} \mathrm{Q}_{3}=86,75$. 


\section{BESTARI}

Vol. 17, No. 1, 2020

p-ISSN 1907-1337; e-ISSN 2807-6532

5) Persentil (P)-nya adalah sebagai berikut: $P_{25}=73,25 ; P_{50}=82,00$; $\mathrm{P}_{75}=86,75$;

2. Efektivitas Pembelajaran PAI

Hasil pengolahan secara deskriptif terhadap variabel efektivitas pembelajaran Pendidikan Agama Islam diperoleh gambaran sebagai berikut.

Tabel 3. Efektivitas Pembelajaran PAI

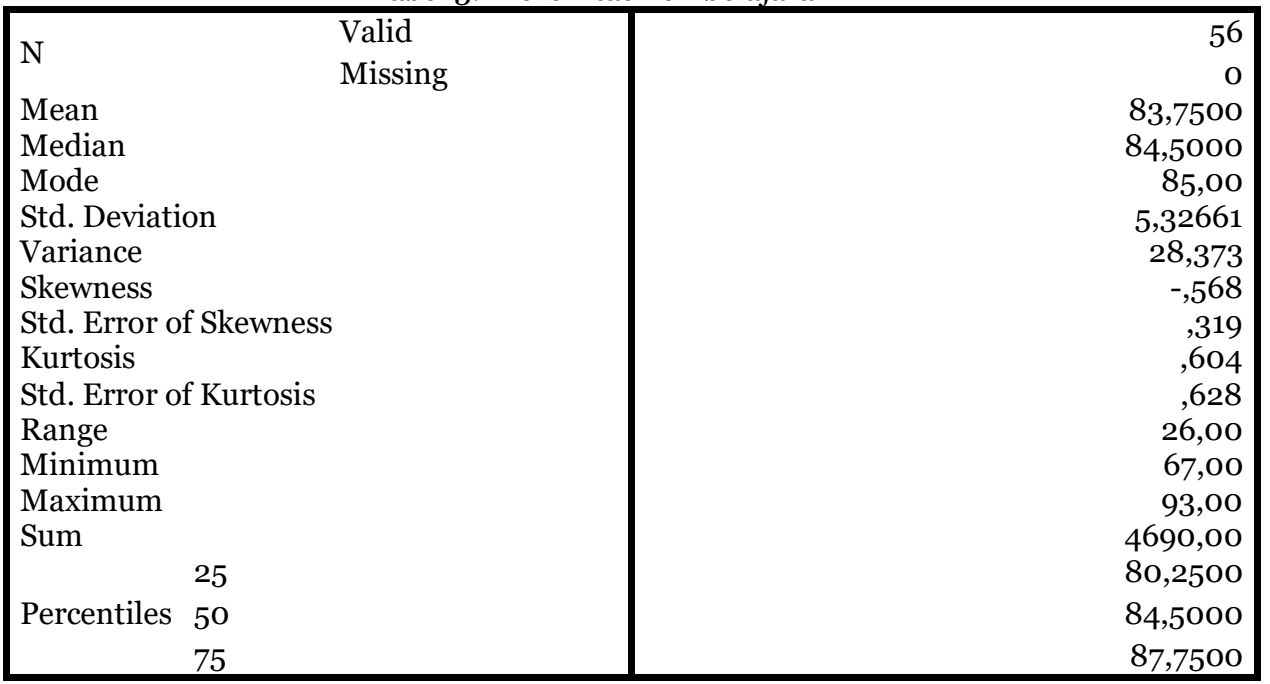

Berdasarkan hasil perhitungan di atas, dapat diketahui bahwa:

a. Tedensi sentral, sebagai berikut:

1) Mean sebesar 83,75 . Harga mean tersebut peneliti konversikan dengan menggunakan pedoman konversi sebagaimana terlihat dalam tabel di bawah ini:

Tabel 4. Konversi Harga Mean

\begin{tabular}{|c|c|}
\hline Skor & Kualifikasi \\
\hline$\geq 91,73$ & Sangat Tinggi \\
\hline $86,41-91,72$ & Tinggi \\
\hline $81.08-86,40$ & Sedang \\
\hline $75,76-81,07$ & Rendah \\
\hline$\leq 75,75$ & Sangat Rendah \\
\hline
\end{tabular}

Sumber: Sudijono (2015: 175)

Dengan demikian, angka mean sebesar 83,75 tergolong sedang, sebab berada pada kisaran 81,08 sampai dengan 86,40 .

2) Mediannya adalah 84,50 .

3) Modusnya adalah 85,00.

b. Variabilitasnya, sebagai berikut:

1) Rangenya adalah 26,00 .

2) Standar deviasinya adalah 5,326 .

3) Variannya adalah $28,373$. 
4) Quartil (Q)-nya adalah sebagai berikut: $\mathrm{Q}_{1}=80,25 ; \mathrm{Q}_{2}=84,50 ;$ dan $\mathrm{Q}_{3}=87,75$.

5) Persentil (P)-nya adalah sebagai berikut: $\mathrm{P}_{25}=80,25 ; \mathrm{P}_{50}=84,50 ; \mathrm{P}_{75}=$ 87,75;

Peneliti menggunakan pendekatan Kolmogrov-Smirnov dengan menggunakan SPSS 20.0, dimana prinsip utama uji normalitas yaitu apabila nilai sig $>0,05$, maka sampel dianggap normal dan begitupun sebaliknya, jika nilai sig < 0,05 maka dianggap tidak berdistribusi normal. Uji normalitas dilakukan untuk mengetahui nilai residu dalam penelitian berdistribusi normal atau tidak normal, dan untuk mengetahui apakah syarat representatif sampel penelitian terpenuhi atau tidak. Hasil uji normalitas adalah sebagai berikut.

Tabel 5. Tests of Normality

\begin{tabular}{|c|c|c|c|c|c|c|}
\hline & \multicolumn{3}{|c|}{ Kolmogorov-Smirnova } & \multicolumn{3}{|c|}{ Shapiro-Wilk } \\
\hline & Statistic & Df & Sig. & Statistic & $\mathrm{df}$ & Sig. \\
\hline $\begin{array}{l}\text { Penggunaan Aplikasi } \\
\text { Quizizz } \\
\text { Efektivitas } \\
\text { Pembelajaran PAI }\end{array}$ & $\begin{array}{l}, 136 \\
, 093\end{array}$ & $\begin{array}{l}56 \\
56\end{array}$ & $\begin{array}{r}, 012 \\
, 200^{*}\end{array}$ & $\begin{array}{l}, 950 \\
, 973\end{array}$ & $\begin{array}{l}56 \\
56\end{array}$ & $\begin{array}{l}\text {,021 } \\
\text { 231 }\end{array}$ \\
\hline
\end{tabular}

Berdasarkan pada tabel di atas dapat diketahui bahwa hasil uji normalitas dari variabel Penggunaan Aplikasi Quizizz (X) dan variabel Efektivitas Pembelajaran PAI (Y) adalah sebagai berikut:

Statistik uji Kolmogrov-Smirnov dikatakan sampel berdistribusi normal apabila Sig $>\alpha . \alpha=0.05$.

a. Hasil uji normalitas untuk variabel independen (Penggunaan Aplikasi Quizizz) diperoleh statistik KS Z (Kolmogrov-Smirnov) sebesar 0,012. Diperoleh nilai sig 0,012 berarti $0,012>0,05$, maka dapat diinterpretasikan bahwa variabel independen (Penggunaan Aplikasi Quizizz) memiliki distribusi normal atau data sampel yang normal.

b. Hasil uji normalitas variabel dependen (Efektivitas Pembelajaran PAI) diperoleh statistik KS Z (Kolmogrov-Smirnov) sebesar 0,200. Diperoleh nilai sig 0,200 berarti $0,200>0,05$, maka dapat disimpulkan bahwa variabel Efektivitas Pembelajaran PAI memiliki distribusi normal atau data sampel yang normal.

Peneliti menggunakan uji levene, fisher atau uji barlett dengan menggunakan SPSS 20.0, dimana uji homogenitas yaitu apabila nilai sig $>0,05$, maka sampel dianggap homogeny dan begitupun sebaliknya, jika nilai sig < 0,05 maka dianggap data tidak homogen. Uji homogenitas dimaksudkan untuk mengetahui apakah sampel yang diambil berasal dari populasi dengan varians yang homogen. Pengujian ini digunakan untuk persyaratan sebelum melakukan pengujian hipotesis lain misalnya $\mathrm{T}$ Test dan Anova. 
Tabel 6. Test of Homogeneity of Variances

\begin{tabular}{|c|c|c|c|}
\hline Levene Statistic & df1 & $\mathrm{df2}$ & Sig. \\
\hline 2,636 & 14 & 31 & ,012 \\
\hline
\end{tabular}

Berdasarkan pada tabel di atas dapat diketahui bahwa hasil uji homogenitas dari variabel Penggunaan Aplikasi Quizizz (X) dan variabel Efektivitas Pembelajaran PAI (Y) adalah sebagai berikut:

Uji Levene dikatakan sampel berdistribusi normal apabila Sig $>\alpha . \alpha=$ 0.05 .

a. Hasil uji homogenitas untuk variabel dependen (Efektivitas Pembelajaran PAI) diperoleh sebesar 0,012. Diperoleh nilai sig 0,012 berarti $0,012>0,05$, maka dapat disimpulkan bahwa variabel Efektivitas Pembelajaran PAI memiliki data yang homogen.

Pengujian Hipotesis

Adapun langkah-langkah pengujian yang dilakukan peneliti adalah sebagai berikut:

a. Menuliskan hipotesis

Hipotesis dalam penelitian ini adalah sebagai berikut:

Ho : Tidak terdapat pengaruh antara Penggunaan Aplikasi

Quizizz terhadap efektivitas pembelajaran PAI di SDN 3 Cisaga.

Ha: Terdapat pengaruh antara Penggunaan Aplikasi Quizizz terhadap efektivitas pembelajaran PAI di SDN 3 Cisaga.

b. Menentukan tingkat signifikansi

Tingkat signifikansi yang digunakan oleh peneliti adalah $5 \%$, yang merupakan ukuran standar dalam penelitian. Hal ini senada dengan pendapat Dwi Priyatno (2008: 71). Bahwa tingkat signifikansi 5\% adalah ukuran standar yang sering digunakan dalam penelitian.

c. Menentukan thitung dan $t_{\text {tabel }}$

Tabel 7. Hasil Uji T

Coefficients $^{\mathrm{a}}$

\begin{tabular}{|c|c|c|c|c|c|}
\hline \multirow[t]{2}{*}{ Model } & \multicolumn{2}{|c|}{$\begin{array}{c}\text { Unstandardized } \\
\text { Coefficients } \\
\end{array}$} & $\begin{array}{c}\text { Standardized } \\
\text { Coefficients } \\
\end{array}$ & \multirow[t]{2}{*}{$\mathrm{T}$} & \multirow[t]{2}{*}{ Sig. } \\
\hline & $\mathrm{B}$ & Std. Error & Beta & & \\
\hline $\begin{array}{ll} & \text { (Constant) } \\
1 & \begin{array}{l}\text { Penggunaan Aplikasi } \\
\text { Quizizz }\end{array}\end{array}$ & $\begin{array}{r}46,989 \\
, 458\end{array}$ & $\begin{array}{r}4,546 \\
, 056\end{array}$ & ,742 & $\begin{array}{r}10,335 \\
8,132\end{array}$ & $\begin{array}{l}\text {,000 } \\
\text {,000 }\end{array}$ \\
\hline
\end{tabular}

a. Dependent Variable: Efektivitas Pembelajaran PAI

Berdasarkan hasil analisis regresi sederhana di atas, $t_{\text {hitung }}-$ nya adalah 8,132. Sedangkan $t_{\text {tabel, }}$ dapat dicari dengan menggunakaan tabel 
distribusi t dengan cara: taraf signifikan $\alpha=0,05 / 2=0,025$ (dua sisi), kemudian di cari tabel pada tabel distribusi studenta $t$ dengan ketentuan sebagai berikut:

Derajat kebebasan $(\mathrm{df})=\mathrm{n}-\mathrm{k}-1$

Keterangan:

$$
\begin{aligned}
& =56-1-1 \\
& =54
\end{aligned}
$$

n : Jumlah kasus

$\mathrm{k} \quad$ : Jumlah variabel independen

Dengan demikian hasil yang diperoleh untuk $t_{\text {tabel }}$ adalah 2,004

d. Kaidah pengujian

Kaidah pengujian yang digunakan sebagaimana yang dikemukakan oleh Siregar (2013: 253) adalah:

Jika, $-\mathrm{t}_{\text {tabel }} \leq \mathrm{t}_{\text {hitung }} \leq \mathrm{t}_{\text {tabel }}$, maka Ho diterima.

Jika, $t_{\text {hitung }}>t_{\text {tabel }}$, maka Ho ditolak.

e. Membandingkan $t_{\text {hitung }}$ dengan $t_{\text {tabel }}$

Nilai tabel Coefficient (a) diperoleh nilai $t_{\text {hitung }}$ adalah 8,132 , sedangkan $t_{\text {tabel }}$ adalah 2,004. Jika dibandingkan $t_{\text {hitung }}>t_{\text {tabel }}(8,132>$ 2,004), maka Ho ditolak dan Ha diterima. Yang artinya terdapat perbedaan yang signifikan antara pembelajaran menggunakan aplikasi Quizizz dengan metode pembelajaran konvensional, dengan kata lain penggunaan aplikasi Quizizz efektif digunakan dalam pembelajaran PAI.

Penelitian ini merupakan penelitian eksperimen dengan 1 kelas yang dijadikan sampel penelitian. Penelitian ini bertujuan untuk mengetahui seberapa efektif penggunaan aplikasi Quizizz terhadap efektivitas pembelajaran PAI di SDN 3 Cisaga tahun pelajaram 2018/2019.

Hasil uji normalitas untuk variabel independen (Penggunaan Aplikasi Quizizz) diperoleh statistik KS Z (Kolmogrov-Smirnov) sebesar 0,012. Diperoleh nilai sig 0,012 berarti 0,012 > 0,05,

Uji normalitas dalam penelitian ini diperoleh data dengan taraf signifikansi 0,005 dengan menggunakan KS Z (Kolmogrov-Smirnov) sebesar 0,012. Hal ini dapat disimpulkan bahwa baik data tersebut berdistribusi normal.

Uji homogenitas dalam penelitian ini diperoleh dengan menggunakan uji levene, fisher atau barlett. Uji ini dilakukan untuk mengetahui apakah kelas tersebut terdistribusi homogen atau tidak. Berdasarkan perhitungan menggunakan uji $\mathrm{F}$ (lihat tabel 4.12) diperoleh variabel dependen (Efektivitas Pembelajaran PAI) diperoleh sebesar 0,012. Diperoleh nilai sig 0,012 berarti 0,012 > 0,05, maka dapat disimpulkan bahwa variabel Efektivitas Pembelajaran PAI memiliki data yang homogen.

Uji kesamaan rata-rata ini menggunakan uji dua pihak dengan menggunakan rumus uji-t. Berdasarkan perhitungan menggunakan rumus uji t (lihat tabel 4.13), menunjukkan bahwa thitung $=8,132$ sedangkan ttabel $=2,004$, berdasarkan perhitungan yang telah peneliti 


\section{BESTARI}

Vol. 17, No. 1, 2020

p-ISSN 1907-1337; e-ISSN 2807-6532

lakukan dapat disimpulkan bahwa thitung $=8,132$ sedangkan ttabel $=$ 2,004 dengan taraf signifakn 0,005 dan $\mathrm{df}=56-1-1=54$. Karena thitung $>$ ttabel, dimana thitung sebesar 8,132 dan ttabel 2,004 hal ini berarti tidak ada perbedaan rata-rata dari data tersebut, karena $t$ berada pada daerah penerimaan Ho maka dapat diartikan bahwa tidak terdapat perbedaan rata-rata dari kedua variabel.

Setelah diketahui kesamaan rata-rata dari sampel tersebut, maka peneliti memberikan perlakukan berupa pembelajaran menggunakan aplikasi Quizizz kepada 1 kelas yang dijadikan sampel. Setelah pembelajaran selesai, peserta didik diberikan soal uji pada aplikasi Quizizz ini. Bertujuan untuk mengetahui kemampuan yang dicapai peserta didik setelah berakhirnya pembelajaran. Kemudian hasil uji peserta didik dianalisis kembali untuk mencari normalitas, homogenitas dan perbedaan rata-ratanya. maka hal ini menunjukkan bahwa meningkatkan efektivitas pembelajaran PAI menggunakan aplikasi Quizizz lebih baik dibandingkan pembelajaran menggunakan konvensional dengan kata lain pembelajaran menggunakan aplikasi Quizizz efektif terhadap peningkatan hasil belajar peserta didik kelas atas di SDN 3 Cisaga tahun 2018/2019.

Dengan adanya pelaksanaan pembelajaran dengan menggunakan aplikasi Quizizz diharapkan dapat meningkatkan hasil belajar peserta didik, selain itu juga dapat mengembangkan potensi peserta didik juga kreativitas peserta didik. Hal ini menunjukkan bahwa pembelajaran menggunakan aplikasi Quizizz dapat meningkatkan hasil belajar (psikomotorik dan kognitif) peserta didik pada mata pelajaran PAI.

\section{KESIMPULAN}

Berdasarkan hasil penelitian dan pembahasan yang telah dilakukan pada bab sebelumnya, peneliti dapat mengambil kesimpulan sebagai berikut:

1. Penggunaan Aplikasi Quizizz di SDN 3 Cisaga tergolong sedang. Hal ini didasarkan atas mean yang diperoleh untuk data variabel $\mathrm{X}$ (penggunaan aplikasi Quizizz) yaitu 80,17, kemudian ketika dikonversikan dengan pedoman konversi harga mean berada pada kisaran 75,86 sampai dengan 84,46, dengan kualifikasi sedang.

2. Efektivitas Pembelajaran PAI di SDN 3 Cisaga tergolong sedang. Hal ini didasarkan atas mean yang diperoleh untuk data variabel $\mathrm{Y}$ (efektivitas pembelajaran PAI) yaitu 83,75, kemudian ketika dikonversikan dengan pedoman konversi harga mean berada pada kisaran 81,08 sampai dengan 86,40, dengan kualifikasi sedang.

3. Penggunaan Aplikasi Quizizz di SDN 3 Cisaga tergolong sedang. Hal ini didasarkan atas mean yang diperoleh untuk data variabel $\mathrm{X}$ (penggunaan aplikasi Quizizz) yaitu 80,17, kemudian ketika dikonversikan dengan pedoman konversi harga mean berada pada kisaran 75,86 sampai dengan 84,46, dengan kualifikasi sedang. 
4. Penggunaan Aplikasi Quizizz di SDN 3 Cisaga memiliki pengaruh terhadap efektivitas pembelajaran PAI di SDN 3 Cisaga. Hal ini ditunjukkan dari perhitungan yang telah dilakukan oleh peneliti, dari hasil hitungan diperoleh melalui uji signifikan koefisien korelasi pada taraf signifikansi $5 \%$ diperoleh $t_{\text {hitung }}>\mathrm{t}_{\text {tabel }}(8.132>2,003)$ dan nilai sig atau probabilitas < 0,05 (0,000 < 0,05), menunjukkan bahwa secara statistik penggunaan aplikasi Quizizz berpengaruh signifikan terhadap efektivitas pembelajaran PAI sehingga Ha diterima dan Ho ditolak. Dengan demikian hipotesis yang menyatakan bahwa terdapat pengaruh antara Penggunaan Aplikasi Quizizz terhadap efektivitas pembelajaran PAI di SDN 3 Cisaga dinyatakan diterima.

\section{DAFTAR PUSTAKA}

Darajat, Zakiyah. (2008). Ilmu Pendidikan Islam. Jakarta: Bumi Aksara. Gunawan, Ce. (2020). Mahir Menguasai SPSS Panduan Praktis Mengolah Data Penelitian. Yogyakarta: Deepublish.

Hamdi, Asep Saepul \& Bahruddin, E. (2014). Metode Penelitian Kuantitatif Aplikasi Dalam Pendidikan. Yogyakarta: Deepublish.

Herlina \& Habibi, Baso. (2016). Inovasi Teknologi Pembelajaran Berbasis Mobile Learning. Prosiding SENTIA, 8, A254-A259.

Herlina, Vivi. (2019). Panduan Praktik Mengolah Data Kuisioner Menggunakan SPSS. Jakarta: Elex Media Komputindo.

Jalinus, Nizwardi \& Ambiyar. (2016). Media dan Sumber Pembelajaran. Jakarta: Kencana.

Majid, Abdul \& Andayani, Dian. (2006). Pendidikan Agama Islam Berbasis Kompetensi (Konsep dan Implementasi Kurikulum 2004). Bandung: Ramaja Rosdakarya.

Noor, Sugian. (2020). Penggunaan Quizizz Dalam Penilaian Pembelajaran Pada Materi Ruang Lingkup Biologi Untuk Meningkatkan Hasil Belajar Peserta didik Kelas X.6 Sma 7 Banjarmasin. Jurnal Pendidikan Hayat, 1(1), 1-7.

Payadnya, I Putu Ade Andre \& Jayantika, I Gusti Agung Ngurah Trisna. (2018). Panduan Penelitian Eksperimen Beserta Analisis Statistik dengan SPSS. Yogyakarta: Deepublish.

Priyatno, Dwi. (2008). Mandiri Belajar SPSS. Yogyakarta: MediaKom.

Purba, Leony Sanga Lamsari. (2019). Peningkatan Konstentrasi Belajar Mahapeserta didik Melalui Pemanfaatan Evaluasi Pembelajaran Quizizz Pada Mata Kuliah Kimia Fisika I. JDP, 12(1), 29-39.

Pusat Bahasa Departemen Pendidikan Nasional. (2005). Kamus Besar Bahasa Indonesia. Jakarta: Balai Pustaka.

Riyanto, Slamet \& Hatmawan, Aglis Andhita. (2020). Metode Riset Penelitian Kuantitatif Penelitian di Bidang Manajemen, Teknik, Pendidikan, dan Eksperimen. Yogyakarta: Deepublish. 


\section{BESTARI}

Vol. 17, No. 1, 2020

p-ISSN 1907-1337; e-ISSN 2807-6532

Sarmanu. (2017). Dasar Metodologi Penelitian. Surabaya: Airlangga University Press.

Sudijono, Anas. (2015). Pengantar Statistik Pendidikan. Jakarta: Rajawali Press.

Switri, Endang. (2019). Teknologi dan Media Pendidikan Dalam Pembelajaran. Pasuruan: Qiara Media.

Wicaksono, Yudhy. (2005). Aplikasi Excel dalam Menganalisis data. Jakarta: PT Elex Media Komputindo. 
